\title{
Glacier response to North Atlantic climate variability during the Holocene
}

\author{
N. L. Balascio ${ }^{1,2}$, W. J. D'Andrea ${ }^{1}$, and R. S. Bradley ${ }^{3}$ \\ ${ }^{1}$ Lamont-Doherty Earth Observatory of Columbia University, Palisades, NY 10964, USA \\ ${ }^{2}$ Department of Geology, College of William \& Mary, Williamsburg, VA 23187, USA \\ ${ }^{3}$ Department of Geosciences, University of Massachusetts, Amherst, MA 01003, USA \\ Correspondence to: N. L. Balascio (nbalascio@wm.edu)
}

Received: 16 April 2015 - Published in Clim. Past Discuss.: 27 May 2015

Revised: 23 October 2015 - Accepted: 27 October 2015 - Published: 4 December 2015

\begin{abstract}
Small glaciers and ice caps respond rapidly to climate variations, and records of their past extent provide information on the natural envelope of past climate variability. Millennial-scale trends in Holocene glacier size are well documented and correspond with changes in Northern Hemisphere summer insolation. However, there is only sparse and fragmentary evidence for higher-frequency variations in glacier size because in many Northern Hemisphere regions glacier advances of the past few hundred years were the most extensive and destroyed the geomorphic evidence of ice growth and retreat during the past several thousand years. Thus, most glacier records have been of limited use for investigating centennial-scale climate forcing and feedback mechanisms. Here we report a continuous record of glacier activity for the last $9.5 \mathrm{ka}$ from southeast Greenland derived from high-resolution measurements on a proglacial lake sediment sequence. Physical and geochemical parameters show that the glaciers responded to previously documented Northern Hemisphere climatic excursions, including the " $8.2 \mathrm{ka}$ " cooling event, the Holocene Thermal Maximum, Neoglacial cooling, and 20th century warming. In addition, the sediments indicate centennial-scale oscillations in glacier size during the late Holocene. Beginning at $4.1 \mathrm{ka}$, a series of abrupt glacier advances occurred, each lasting $\sim 100$ years and followed by a period of retreat, that were superimposed on a gradual trend toward larger glacier size. Thus, while declining summer insolation caused long-term cooling and glacier expansion during the late Holocene, climate system dynamics resulted in repeated episodes of glacier expansion and retreat on multi-decadal to centennial timescales. These episodes coincided with ice rafting events in the North
\end{abstract}

Atlantic Ocean and periods of regional ice cap expansion, which confirms their regional significance and indicates that considerable glacier activity on these timescales is a normal feature of the cryosphere. The data provide a longer-term perspective on the rate of 20th century glacier retreat and indicate that recent anthropogenic-driven warming has already impacted the regional cryosphere in a manner outside the natural range of Holocene variability.

\section{Introduction}

Glaciers and ice caps represent a small but important portion of the cryosphere $\left(\sim 785000 \mathrm{~km}^{2}\right.$; Dyurgerov and Meier, 2005). Their mass wasting during the 20-21st century is responsible for $60 \%$ of the sea-level rise unattributable to ocean warming (Meier, 2007) and they continue to retreat at an exceptional rate (Zemp et al., 2012). Moreover, because small glaciers and ice caps respond rapidly to climate changes and there is a strong relationship between glacier mass balance and summer temperature (Oerlemans, 2005), past glacier extent can inform us about past climate variability.

Holocene glacier activity in the Arctic is reasonably well documented at millennial timescales (Miller et al., 2010). Northern Hemisphere glaciers receded in the early Holocene and were smaller than present during the midHolocene. Centennial-scale variations, however, are not well constrained because there are few high-resolution and continuous records, and because in many regions the most extensive glacier advances since the early Holocene took place 
within the past few hundred years, destroying geomorphic evidence of intervening glacier positions. This is the case in Greenland, where historical (AD 1200-1940) advances of local glaciers were generally the most extensive since at least the early Holocene (Kelly and Lowell, 2009).

Evidence from the Greenland Ice Sheet (Kobashi et al, 2011), marine sediments (Bond et al., 1997; Thornalley et al., 2009; Moffa-Sánchez et al., 2014; Jiang et al., 2015), and terrestrial archives (D'Andrea et al., 2011; Larsen et al., 2012; Olsen et al., 2012) indicate that abrupt changes in atmospheric circulation and ocean dynamics, including abrupt cooling events, have punctuated the Holocene. These episodes have alternately been attributed to solar variability, freshwater forcing, volcanic activity, and/or changes in Atlantic Meridional Overturning Circulation (Wanner et al., 2011). How sensitive were glaciers to these abrupt episodes, and did glaciers throughout the North Atlantic respond uniformly? During the period from AD 1250-1900, often referred to as the "Little Ice Age", well-resolved records from the North Atlantic region suggest coherence in ice cap activity that was potentially driven by volcanic activity coupled with sea-ice/ocean feedbacks (Miller et al., 2012). However, prior to the last 1000 years there are sparse data for use in investigating the synchrony of glacier response to climate variability in the North Atlantic region.

Lakes that receive meltwater from temperate glaciers can be used to develop continuous records of glacier activity. Bedrock erosion at the base of glaciers provides sediment supply for meltwater transport to proglacial lakes. In catchments where other sources of sediment are limited (such as from mass wasting, paraglacial effects, or the release of stored sediment) there is a strong relationship between sediment properties and glacier size (Nesje et al., 2000; Dahl et al., 2003; Jansson et al., 2005), which also follows from the assumption that large glaciers produce more minerogenic material and meltwater than small glaciers. Measurements of physical and geochemical properties of proglacial lake sediments can therefore be used to reconstruct records of past glacier size. Here we report a continuous $9.5 \mathrm{ka}$ record of glacier activity on Kulusuk Island, southeast Greenland developed using sediment cores recovered from Kulusuk Lake $\left(65.56^{\circ} \mathrm{N}, 37.11^{\circ} \mathrm{W} ; 202 \mathrm{~m}\right)$ (Fig. 1). We characterize changes in sedimentation using measurements of physical sediment properties, including the following: bulk density, organic matter content, magnetic susceptibility, and accumulation rates. We also measured the relative elemental compositions of the sediment using scanning X-ray fluorescence (XRF) to characterize minerogenic changes at higher resolution and with greater sensitivity. These data provide detailed information on sedimentation in Kulusuk Lake related to glacier input.

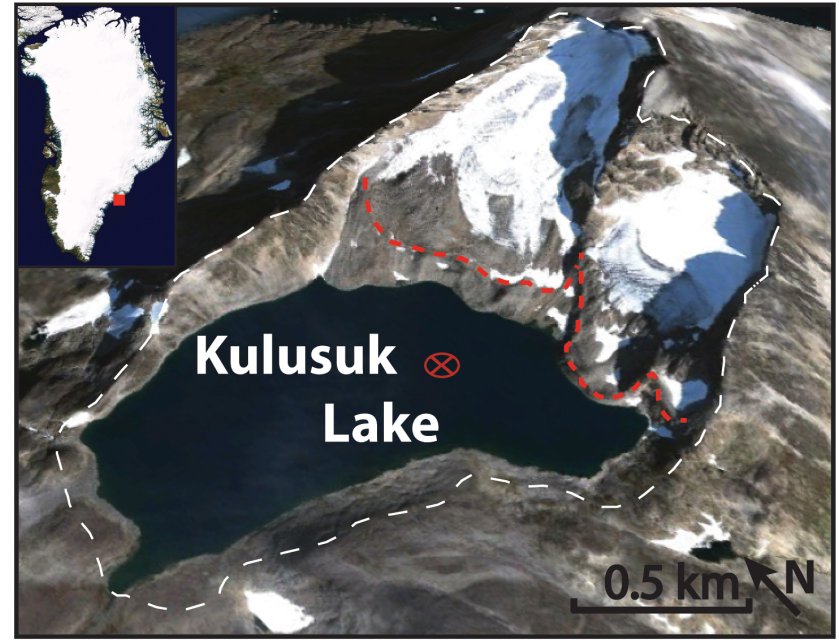

Figure 1. Location and catchment setting of Kulusuk Lake. The white dashed line marks the watershed boundary and the red dashed line defines the crest of moraines in front of both glaciers mapped in the field. Cores were collected in the deepest basin (red circle). Image: Google, NASA.

\section{Study site}

Kulusuk Lake $\left(0.8 \mathrm{~km}^{2}, 69 \mathrm{~m}\right.$ maximum depth) is located below a cirque with two small glaciers and is within a low arctic maritime region (MAT $-1{ }^{\circ} \mathrm{C}$, MAP $900 \mathrm{~mm}$ ). Characteristic erosional features indicate that local glaciers have temperate thermal structures (Humlum and Christiansen, 2008). Distinct moraines defined by sharp crests are located in front of both glaciers, and the recently glaciated area accounts for $\sim 50 \%$ of the catchment, which is composed of Archaen gneisses (Bridgwater, 1976) (Fig. 1). Kulusuk Lake is ideally situated to capture and preserve a clear sedimentary record of glacier activity because (i) it only receives runoff from a very small catchment (catchment : lake area ratio of $\sim 2: 1$ ), minimizing the potential for long-term storage of sediments prior to deposition and limiting sediment input from non-glacial processes, (ii) the proximity of the glaciers to the lake results in minimal sediment transport distance, and (iii) the small size of the glaciers makes them sensitive to minor climate variations (Fig. 1). Therefore, bedrock erosion by the glaciers provides the primary source of minerogenic sediment to the lake and changes in glacier size should clearly be reflected in sediment properties.

\section{Methods}

\subsection{Sediment core collection and analysis}

Sediment cores were recovered from Kulusuk Lake in April 2010 when the lake was ice covered. Bathymetric measurements were made manually through holes drilled in the ice, and sediment cores were collected using Uwitec grav- 
ity and percussion coring devices from the deepest location, which has a water depth of $69 \mathrm{~m}$. A composite $3.5 \mathrm{~m}$ record was compiled by matching the physical stratigraphy and scanning XRF profiles from a $26 \mathrm{~cm}$ gravity core (Kul-10DB) and multiple overlapping percussion cores (Kul-10G-A1, -B1, -A2).

The magnetic susceptibility of the cores was measured every $0.5 \mathrm{~cm}$ using a Bartington MS2E sensor. The organicmatter content of the cores was measured by loss-on-ignition (LOI) on contiguous $1-\mathrm{cm}^{3}$ samples taken at $1 \mathrm{~cm}$ intervals. Organic-matter content was calculated as the difference between the weight of dried $1-\mathrm{cm}^{3}$ samples and their weight after heating for $4 \mathrm{~h}$ at $550^{\circ} \mathrm{C}$ (Dean, 1974). Bulk density measurements $\left(\mathrm{g} \mathrm{cm}^{-3}\right)$ and the calculated sedimentation rates $\left(\mathrm{cm} \mathrm{year}^{-1}\right)$ were used to determine mass accumulation rates (MAR; $\mathrm{g} \mathrm{cm}^{-2}$ year $^{-1}$ ). Grain size measurements were made at $10 \mathrm{~cm}$ increments. Samples were pre-treated with a $30 \%$ hydrogen peroxide solution to digest organic material and analyzed using a Beckman Coulter LS200 particle-size analyzer.

\subsection{Chronology}

An age-depth model was established based on ${ }^{210} \mathrm{~Pb}$ analysis of the upper sediments and AMS radiocarbon dates on macrofossils. The ${ }^{210} \mathrm{~Pb}$ activity of samples taken every $1 \mathrm{~cm}$ from the upper $10 \mathrm{~cm}$ of the record was measured by Flett Research Ltd. (Winnipeg, Canada), and ages were modeled from these data using a constant rate of supply model. AMS radiocarbon measurements were made on plant/wood fragments and Daphnia ephippia that were wet sieved from core samples. All radiocarbon ages were calibrated to calendar years using CALIB v. 6.0 (Stuiver and Reimer, 1993) with the IntCal09 calibration data set (Reimer et al., 2009). Ages are presented in calendar years prior to AD 1950 (BP) unless otherwise indicated.

\subsection{Scanning X-ray fluorescence}

To characterize minerogenic changes at higher resolution and with greater sensitivity, an Itrax ${ }^{\mathrm{TM}}$ XRF core scanner was used to produce profiles of relative elemental compositions (Croudace et al., 2006). The Itrax ${ }^{\mathrm{TM}}$ continuously scans the surface of sediment cores at sub-mm resolution with a micro $\mathrm{X}$-ray beam $(20 \mathrm{~mm} \times 100 \mu \mathrm{m})$, and the relative concentrations of a range of elements are determined based on the detection of dispersive energy spectra. Dispersive energy spectra are acquired across each measured interval, and peak area integrals are calculated for each element. Peak area integrals are related to elemental concentrations within the sediment, but can also be influenced by characteristics of the sedimentary matrix and therefore only indicate relative changes in elemental composition (Croudace et al., 2006; Rothwell et al., 2006). Our analysis focused on the elements K, Ca, Ti, $\mathrm{Mn}, \mathrm{Fe}, \mathrm{Zn}, \mathrm{Rb}, \mathrm{Sr}$, which have detection limits that range from 150 to $5 \mathrm{ppm}$ (Croudace et al., 2006). All of the cores were scanned at $200 \mu \mathrm{m}$ intervals with an exposure time of $10 \mathrm{~s}$, voltage of $30 \mathrm{kV}$, and current of $55 \mathrm{nA}$.

\section{Results}

\subsection{Sediment stratigraphy and chronology}

The $3.5 \mathrm{~m}$ composite sediment record from Kulusuk Lake contains distinct lithologic changes, defined by visual stratigraphy, magnetic susceptibility, organic matter content, and elemental data acquired by scanning XRF. The record can be divided into four lithologic units (Fig. 2). Unit I, $3.0-3.5 \mathrm{~m}$, is a gravelly sand. Unit II, from 3.0 to $1.8 \mathrm{~m}$, is a massive gray clayey silt. There is an abrupt transition to Unit III, a brown, organic-rich sediment that extends from 1.8-1.2 m. Unit IV, $1.2-0 \mathrm{~m}$, is a laminated sequence with frequent sandy layers. Laminations consist of fining-upward sequences and impart strong variability in all data sets.

Chronologic data show that there are significant changes in sedimentation rate that correspond to lithostratigraphic units (Fig. 2). An age-depth model was generated assuming that changes in sedimentation rate occurred at the boundaries of these units. In Unit IV, a third-order polynomial was applied to the radiocarbon ages, the core top date that represents when the cores were collected in AD 2010 ( -60 cal yr BP), and the date of the base of the $210 \mathrm{~Pb}$ profile at $10 \mathrm{~cm}$ (111 cal yr BP) (Table 1). This relationship was extrapolated to the base of Unit IV. Linear interpolation between the remaining radiocarbon ages was used to generate the agedepth relationship for Units III and II. There is no chronologic control below $215 \mathrm{~cm}$ so we did not interpret sedimentation prior to $9.5 \mathrm{cal} \mathrm{ka} \mathrm{BP}$.

Magnetic susceptibility, organic matter, and mass accumulation rate (MAR) profiles further define these lithologic changes with higher magnetic susceptibility values across intervals with coarser sediment and with lower organic content (Fig. 3). Moderate organic matter, $5 \%$, and magnetic susceptibility, $\sim 400$ SI $10^{-5}$, values characterize the interval from $2.5-1.8 \mathrm{~m}$. From $1.8-1.6 \mathrm{~m}$, magnetic susceptibility values decrease to zero and organic matter values increase to $19 \%$ (with the exception of two brief intervals of decreased values at 176 and $171 \mathrm{~cm}$ ) and remain elevated to $1.4 \mathrm{~m}$. From 1.4-1.2 m, organic content declines and magnetic susceptibility values increase and then display more minor fluctuations across the upper $1.2 \mathrm{~m}$. These intervals are clearly defined by MARs, which incorporate sediment density measurements that range from $\sim 0.8-1.8 \mathrm{~g} \mathrm{~cm}^{-3}$, but are primarily controlled by the large sedimentation rate changes (Fig. 2).

\subsection{Scanning XRF data analysis}

Elemental scans acquired by scanning XRF show a response similar to magnetic susceptibility with higher values across 


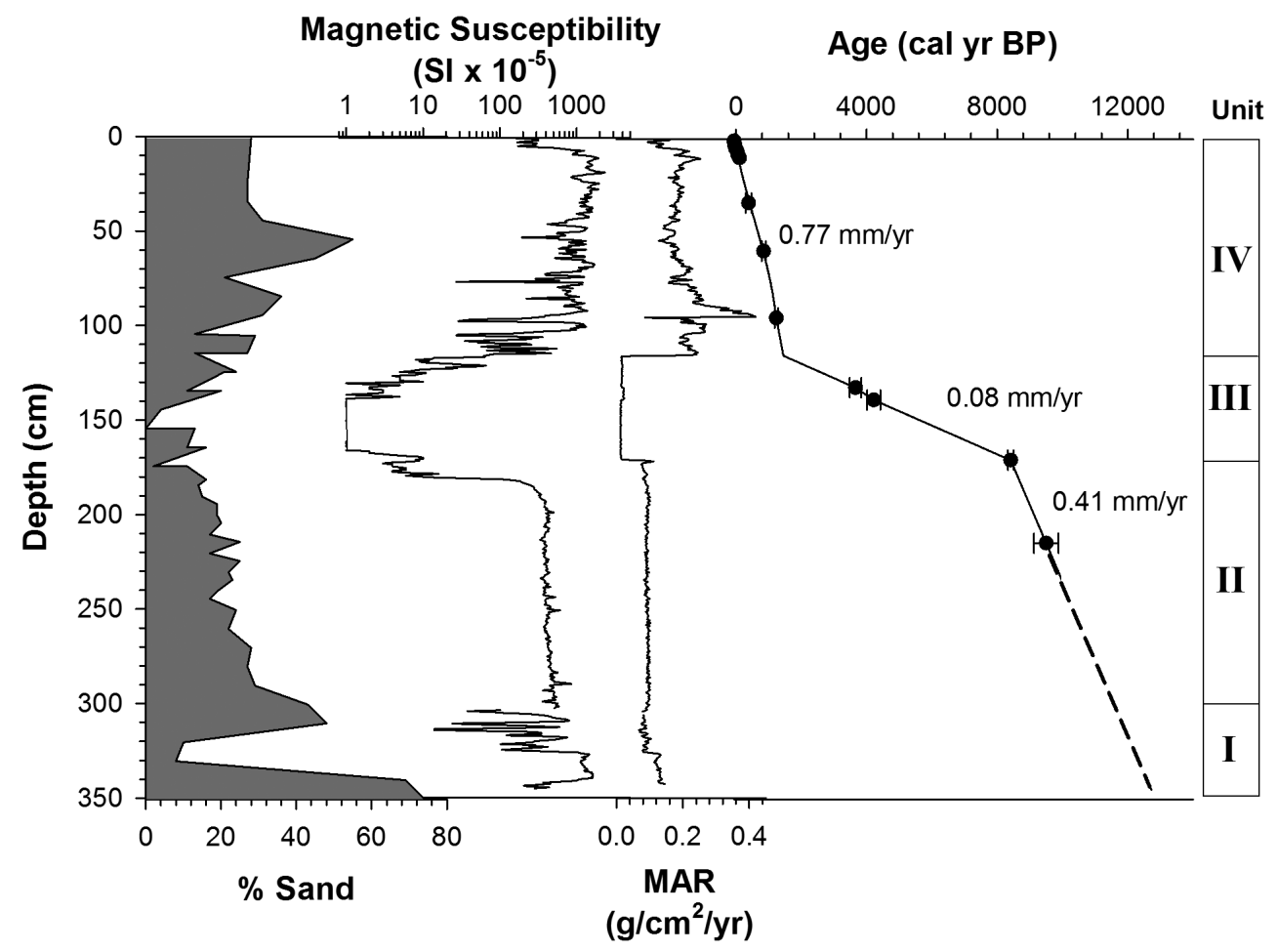

Figure 2. Magnetic susceptibility profile, percent sand, and mass accumulation rate (MAR) shown next to the age-depth model for the composite Kulusuk Lake record. The four lithostratigraphic units and the corresponding sedimentation rates are shown. A dash line marks the period below the last radiocarbon age $(9.5 \mathrm{cal} \mathrm{ka} \mathrm{BP})$ where rates of sedimentation are extrapolated.

Table 1. Geochronologic data for the Kulusuk Lake record.

\begin{tabular}{|c|c|c|c|c|c|c|}
\hline \multirow{2}{*}{$\begin{array}{l}\text { Composite } \\
\text { depth } \\
(\mathrm{cm})\end{array}$} & \multirow[t]{2}{*}{ Description } & \multirow{2}{*}{$\begin{array}{l}\text { Laboratory } \\
\mathrm{ID}^{\mathrm{a}}\end{array}$} & \multirow{2}{*}{$\begin{array}{l}{ }^{14} \mathrm{C} \text { age } \\
\text { (yr BP) }\end{array}$} & \multicolumn{2}{|c|}{ Calibrated age range } & \multirow{2}{*}{$\begin{array}{r}\text { Median age } \\
\text { (cal yr BP) }\end{array}$} \\
\hline & & & & $(1 \sigma)$ & $(2 \sigma)$ & \\
\hline 0 & Core Top & - & - & - & - & -60 \\
\hline 1 & ${ }^{210} \mathrm{~Pb}$ & - & - & - & - & -53 \\
\hline 2 & ${ }^{210} \mathrm{~Pb}$ & - & - & - & - & -46 \\
\hline 3 & ${ }^{210} \mathrm{~Pb}$ & - & - & - & - & -36 \\
\hline 4 & ${ }^{210} \mathrm{~Pb}$ & - & - & - & - & -25 \\
\hline 5 & ${ }^{210} \mathrm{~Pb}$ & - & - & - & - & -7 \\
\hline 6 & ${ }^{210} \mathrm{~Pb}$ & - & - & - & - & 24 \\
\hline 7 & ${ }^{210} \mathrm{~Pb}$ & - & - & - & - & 44 \\
\hline 8 & ${ }^{210} \mathrm{~Pb}$ & - & - & - & - & 57 \\
\hline 9 & ${ }^{210} \mathrm{~Pb}$ & - & - & - & - & 83 \\
\hline 10 & ${ }^{210} \mathrm{~Pb}$ & - & - & - & - & 111 \\
\hline 34 & Daphnia ephippia & OS-96479 & $335 \pm 40$ & $316-459$ & $306-486$ & 393 \\
\hline 59.5 & Plant/wood & UCI-89386 & $940 \pm 20$ & 798-914 & 795-919 & 852 \\
\hline 95 & Daphnia ephippia & OS-96454 & $1290 \pm 25$ & $1183-1276$ & $1178-1283$ & 1237 \\
\hline 132 & Plant/wood & UCI- 87240 & $3410 \pm 60$ & $3574-3814$ & $3484-3832$ & 3664 \\
\hline 138.5 & Plant/wood & UCI-87241 & $3820 \pm 60$ & $4095-4378$ & $4008-4415$ & 4224 \\
\hline 170.5 & Daphnia ephippia & OS-96461 & $7620 \pm 50$ & $8377-8452$ & $8359-8539$ & 8418 \\
\hline 214.5 & Daphnia ephippia & OS-96746 & $8510 \pm 130$ & 9312-9659 & $9135-9887$ & 9501 \\
\hline
\end{tabular}

${ }^{a}$ UCI - University of California Irvine Keck-CCAMS Facility; OS - National Ocean Sciences AMS Facility 
Table 2. XRF PC1 factor loadings and correlation matrix for scanning XRF elemental data.

\begin{tabular}{lrrrrrrrrr}
\hline & $\begin{array}{r}\text { PC1 } \\
\text { loadings }\end{array}$ & K & $\mathrm{Ca}$ & $\mathrm{Ti}$ & $\mathrm{Mn}$ & $\mathrm{Fe}$ & $\mathrm{Zn}$ & $\mathrm{Rb}$ & $\mathrm{Sr}$ \\
\hline $\mathrm{K}$ & 0.950 & 1 & & & & & & & \\
$\mathrm{Ca}$ & 0.868 & 0.891 & 1 & & & & & & \\
$\mathrm{Ti}$ & 0.969 & 0.938 & 0.797 & 1 & & & & & \\
$\mathrm{Mn}$ & 0.815 & 0.672 & 0.594 & 0.783 & 1 & & & & \\
$\mathrm{Fe}$ & 0.945 & 0.876 & 0.748 & 0.946 & 0.814 & 1 & & & \\
$\mathrm{Zn}$ & 0.861 & 0.759 & 0.609 & 0.842 & 0.727 & 0.836 & 1 & & \\
$\mathrm{Rb}$ & 0.831 & 0.743 & 0.601 & 0.791 & 0.637 & 0.790 & 0.727 & 1 & \\
$\mathrm{Sr}$ & 0.686 & 0.689 & 0.803 & 0.583 & 0.412 & 0.488 & 0.436 & 0.455 & 1 \\
\hline
\end{tabular}

coarser, clastic intervals. However, the XRF data have a greater sensitivity to minerogenic changes and were measured at higher resolution $(0.2 \mathrm{~mm})$ (Fig. 3). We focused our analysis on the following elements: $\mathrm{K}, \mathrm{Ca}, \mathrm{Ti}, \mathrm{Mn}, \mathrm{Fe}$, $\mathrm{Zn}, \mathrm{Rb}$, and $\mathrm{Sr}$, which are common in siliciclastic sediments. Changes in the concentrations of these elements reflect changes in the contribution of minerogenic material eroded from catchment bedrock and delivered to the lake. Statistical analysis of the scanning XRF data indicates that all of the elements are highly correlated and that there is a strong primary trend in the data. Correlation coefficients show the strong significant relationships among the majority of the elements (Table 2). Rather than relying on a single element (e.g., Ti), we used principal component analysis (PCA) to define the leading mode of variability (PC1) among the elemental data. PCA allows for a multidimensional examination of the data set in order to identify the primary signal(s). PCA results indicate that there is one strong primary trend in the elemental data with the first eigenvector (PC1) accounting for $76 \%$ of the total variance. The factor loadings reveal the high correlations between individual element profiles and PC1 (Table 2). The trends in PC1 are similar to those in the lower-resolution magnetic susceptibility and organic matter content records, justifying use of PC1 data to infer past minerogenic changes (Fig. 3). The choice to use $\mathrm{PC} 1$ rather than a single representative element (e.g., Ti) to represent changes in sedimentary minerogenic content has no impact on any of our conclusions.

\section{Discussion}

\subsection{Sedimentation in proglacial lakes}

Sedimentation in proglacial lakes can be the result of a complex set of physical processes associated with the erosion, storage, and transport of sediment within glacial and proglacial systems (Dahl et al., 2003; Jansson et al., 2005). It is important to consider these complicating factors when selecting sites for glacier reconstructions and when interpreting sedimentary records. Glaciers fundamentally impact the amount and character of minerogenic sediment in proglacial lakes. Glacier size, erosive ability, and meltwater production directly influence the amount of minerogenic sediment delivered to a proglacial lake. However, sedimentation in a proglacial lake can also be impacted by mass wasting processes in paraglacial environments (particularly in landscapes with steep unstable slopes), and by the delayed release of sediment stored along the transport pathway between the glacier and the lake (for example, sediment stored in extensive meltwater stream channels). Relative to minerogenic material, organic sedimentation is typically a minor component in proglacial lakes and is related to the input of organic matter from autochthonous and allochthonous primary productivity, and the preservation thereof. In proglacial environments in the Arctic, low temperatures restrict vegetation and soil cover, and minerogenic sediment input to lakes from glacial meltwater results in turbidity that impedes autochthonous productivity.

Techniques for analyzing sediment from proglacial lakes therefore focus on investigating changes in the character of minerogenic sediment. The minerogenic content of lake sediments, used as a proxy for glacier size, is commonly evaluated by measuring the magnetic susceptibility and organic matter content of the sediments. The abundances of the major elements from bedrock material (measured by XRF) similarly serve as a proxy for the relative contribution of minerogenic material, versus organic matter, to the lake. Magnetic susceptibility reflects the amount of magnetic minerals eroded and input to a lake, the abundance of major elements from bedrock (measured by XRF) also reflects the relative contribution of minerogenic material input to the lake, and organic matter content is a function of dilution by minerogenic input, changes in primary productivity, and preservation.

At Kulusuk Lake, processes that can complicate the mechanistic link between minerogenic input and glacier size are fundamentally limited. Input of sediment from non-glacial processes is restricted due to the small catchment and small catchment to lake-area ratio $(\sim 2: 1)$, and the proximity of the glaciers to the lake. These factors also limit the potential for sediment storage between the glaciers and the lake. Furthermore, the landscape surrounding the lake is composed 


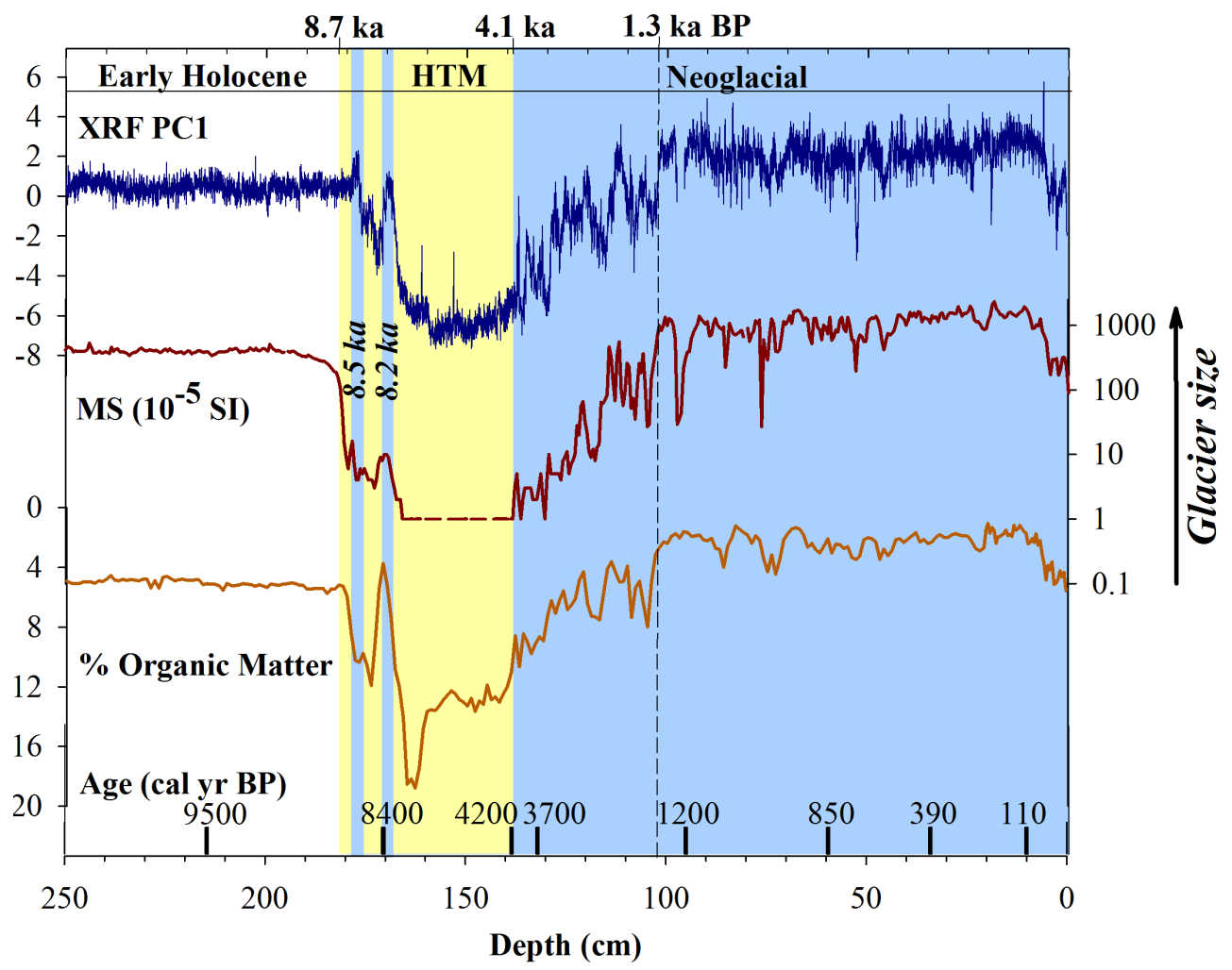

Figure 3. Kulusuk Lake record. (Top) First principal component of the scanning XRF data (PC1). (Middle) Magnetic susceptibility presented on a log scale. A dotted line defines the interval from $165-140 \mathrm{~cm}$ where some zero values were measured. (Bottom) Organic-matter content. Black bars indicate the location and age of chronologic control points (Table 1). The yellow shaded region on the PC1 plot shows where we have interpreted little to no glacier ice in the catchment during the Holocene Thermal Maximum (HTM). Blue shading defines the Neoglacial period when ice was reformed during the late Holocene (4.1 ka-present).

of shallow, low-elevation slopes that minimize the likelihood of mass wasting events. Therefore, at Kulusuk Lake, it is reasonable to interpret changes in minerogenic content as a function of glacier size.

Variations in magnetic susceptibility, organic matter content, and scanning XRF data (PC1) represent changes in the relative amount and grain size of minerogenic sediment delivered to Kulusuk over the last $9.5 \mathrm{ka}$ (Fig. 3). Magnetic susceptibility and $\mathrm{PC} 1$ are directly related to, and organic content is inversely proportional to, minerogenic content. The highest magnetic susceptibility and PC1 values correspond to intervals with coarser grain size. We therefore interpret the sedimentological system in Kulusuk Lake as follows: during periods of increased glacier size, more coarse minerogenic sediment was eroded from the bedrock and delivered to the lake by meltwater; during periods of smaller glacier size, less minerogenic sediment was deposited and a greater relative proportion of organic matter content accumulated.

\subsection{Holocene glacier fluctuations in southeast Greenland}

Dramatic changes in minerogenic input to Kulusuk Lake over the last $9.5 \mathrm{ka}$ reveal that the size of the Kulusuk glaciers has varied significantly throughout the Holocene (Fig. 3). Beginning ca. $8.7 \mathrm{ka}$, increasing organic matter content and decreasing minerogenic content, inferred from magnetic susceptibility and XRF data, document significant retreat of the Kulusuk glaciers, corresponding closely in time with the deglaciation of a nearby inland catchment ca. $8.4 \mathrm{ka}$ (Balascio et al., 2013), following deglaciation of local coastal areas ca. 11.1-9.5 ka (Long et al., 2008; Roberts et al., 2008). A brief interval of increased minerogenic input shows that this early Holocene retreat was interrupted by an episode of advance at $8.5 \mathrm{ka}$, coeval with reductions in sea surface temperatures and bottom water circulation in the subpolar North Atlantic, as seen in high-resolution marine records (Ellison et al., 2006; Kissel et al., 2013). Another abrupt episode of minerogenic input ca. 8.2 ka signifies another glacier advance. This advance occurred contemporaneously with the largest abrupt Holocene climate cooling event inferred from Greenland ice core records (Thomas et al., 2007), which is 
also marked by the advance of Jakobshavn Isbræ, an outlet glacier of the Greenland Ice Sheet in western Greenland (Young et al., 2011, 2013). The temporal resolution and age control of this section of our record cannot provide new constraints on the exact timing of these events, however it clearly demonstrates the sensitivity of the Kulusuk glaciers to rapid, regional climate events.

Between 7.8-4.1 ka, the Kulusuk glaciers were at their minimum Holocene extent, inferred from low minerogenic content, low MAR, and high organic matter content in the lake sediments (Fig. 3). We interpret this as an interval with little to no glacier ice in the catchment, primarily based on the XRF and magnetic susceptibility data, which are lowest and show reduced variability at this time, relative to the last $4.1 \mathrm{ka}$. This interval is also marked by extremely high organic matter content that is greater than $12 \%$ (with a maximum of $19 \%$ ), suggesting that this period was accompanied by an increase in primary productivity due to a lack of input of glacial flour. If the catchment was completely deglaciated, this indicates that the regional equilibrium-line altitude would have been greater than $\sim 676 \mathrm{~m}$, which is the elevation of the mountain peak above the lake. Magnetic susceptibility remains close to zero throughout the mid-Holocene section of the core and appears insensitive to the minor minerogenic changes inferred from the XRF data, which could be attributed to paraglacial processes or seasonal runoff contributing very minor amounts of clastic sediment. There are two excursions in the $\mathrm{PC} 1$ record during this interval (ca. 7.2 and $6.2 \mathrm{ka}$ ), which we interpret as sediment influxes from paraglacial activity rather than as glacier advances because they are short-lived and do not match the amplitude of variation observed elsewhere. Thus, this record provides well-dated constraints on the Holocene Thermal Maximum (HTM) in this area, which refine previous estimates extrapolated for this region (Kaufman et al., 2004) and is similar to the interval when the Greenland Ice Sheet margin was behind its present limit, broadly constrained to ca. 7-4 ka (Larsen et al., 2015).

At $4.1 \mathrm{ka}$, a sharp increase in XRF- and MS-inferred minerogenic content and decrease in organic matter content indicate the glaciers once again grew large enough to contribute minerogenic material to the lake. The regrowth of the Kulusuk glaciers represents the lowering of the regional snowline, and the precise timing could be considered unique to this catchment. However, the timing is contemporaneous with hydrologic changes at nearby Flower Valley Lake, likely related to an increase in the duration of lake ice cover (Balascio et al., 2013). We propose that this represents significant cooling and the onset of the regional Neoglacial period. The oscillatory and stepwise increase in minerogenic input (decrease in organic matter content) after 4.1 ka suggests that rather than advancing steadily toward their historical extent, the Kulusuk glaciers episodically advanced and retreated at centennial timescales until ca. $1.3 \mathrm{ka}$. After advancing at ca. $1.3 \mathrm{ka}$, they stabilized after $0.7 \mathrm{ka}$ until their rapid 20 th cen- tury retreat (Fig. 3). Importantly, the major sedimentological transitions in the record are all located near radiocarbon dates, thereby maximizing the certainty of their timing and the calculations of sediment accumulation rates. The timing of glacier size variations between radiocarbon-dated intervals since $4.1 \mathrm{ka}$ are interpolated, and we estimate the accuracy to be better than \pm 100 years, the average $2-\sigma$ uncertainty of the ages.

\subsection{Evidence for synchronous regional glacier response during the late Holocene}

The Kulusuk glacier reconstruction documents centennialscale episodes of glacier advance during the Neoglacial (4.1 to $1.3 \mathrm{ka}$ ) coeval with other records of glacier growth in the North Atlantic region. After $4.1 \mathrm{ka}$, six major advances of the Kulusuk glaciers occurred (4.1, 3.9, 3.2, 2.8, 2.1, and $1.3 \mathrm{ka})$ and each successive advance resulted in greater glacier extent (Fig. 4). The progressive increase in glacier size is consistent with declining $\mathrm{NH}$ summer insolation, which is likely the mechanism driving millennial-scale changes in glacier size. However, each episode of glacier advance was followed by a period of retreat (or at least stabilization), suggesting that the glaciers repeatedly grew out of equilibrium with external insolation forcing and then retreated back toward an equilibrium state, indicating centennial-scale variability likely driven by internal climate dynamics. The episodic advances of the Kulusuk glaciers during the past $4.1 \mathrm{ka}$ are similar in timing to the cooling episodes in the North Atlantic Ocean inferred from ice-rafted debris (IRD) identified in marine sediment cores (Bond et al., 1997, 2001) (Fig. 4). Cooling events at these times have also been documented on the East Greenland and Icelandic shelves and attributed to increased strength of the East Greenland Current (Giraudeau et al., 2000; Jennings et al., 2002; Ran et al., 2008). Moreover, the Langjökull ice cap in Iceland advanced along with the Kulusuk glaciers and the North Atlantic IRD events (Larsen et al., 2012) (Fig. 4), and advances of the Bregne ice cap in east Greenland at ca. 2.6 and $1.9 \mathrm{ka}$ (Levy et al., 2014), within chronological uncertainty of the Kulusuk glacier advances ca. 2.8 and $2.1 \mathrm{ka}$, have also been documented. We propose that continuous records of glacier activity around the North Atlantic during the Neoglacial are beginning to show evidence for synchronous glacier response to abrupt episodes of climate change.

It is also worth noting that Winsor et al. (2014) found evidence for an advance of an outlet glacier of the Greenland Ice Sheet in southern Greenland ending at ca. $1.5 \mathrm{ka}$, the timing of which is supported by minimum-limiting radiocarbon ages from the same region dating to ca. $1.2 \mathrm{ka}$ (Bennike and Sparrenbom, 2007). We acknowledge that this is the only location on the ice sheet margin where such a late Holocene advance has been documented, but nonetheless it highlights that changes in the ice margin position are beginning to be constrained more accurately. 


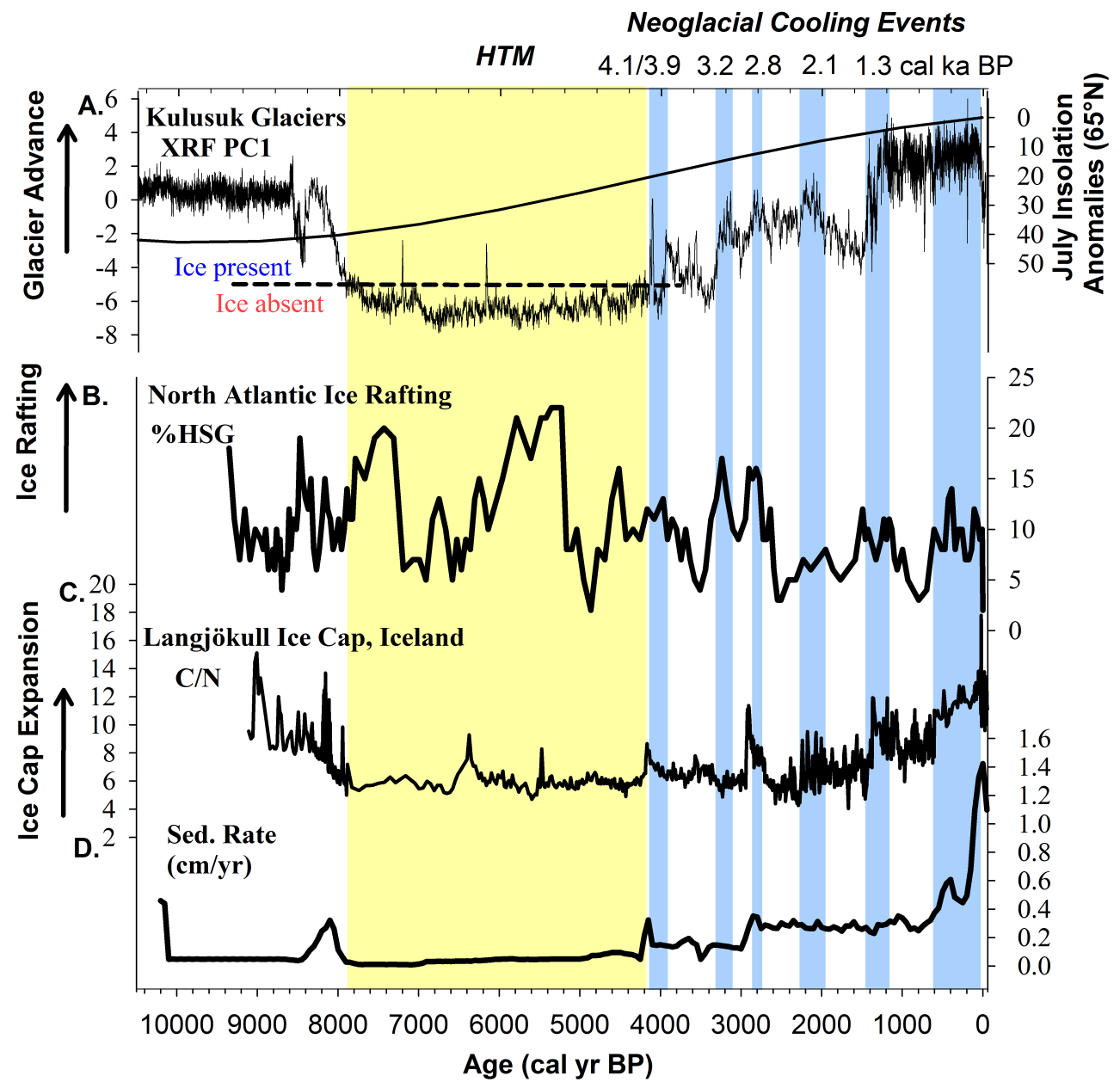

Figure 4. Regional response of glaciers to Holocene climate changes. (a) Kulusuk glaciers interpreted from PC1 data with July insolation anomalies at $65^{\circ} \mathrm{N}$ (Berger and Loutre, 1991). (b) Hematite-stained grains (HSG) identified in core MC52-VM29-191 interpreted to indicate ice-rafting events (Bond et al., 1997). (c) Ratio of total organic carbon to total nitrogen (C / N) and (d) changes in sedimentation rate from Hvítárvatn, interpreted to reflect changes in the size of the Langjökull ice cap, Iceland, and catchment instability in response to climate cooling (Larsen et al., 2012). Yellow shading marks the timing of the Holocene Thermal Maximum (HTM), as interpreted at Kulusuk, and the dashed line on the PC1 plot shows where we have interpreted the absence of ice from the catchment during the HTM. Blue bars highlight intervals of glacier advance and increased ice rafting that define Neoglacial cooling events comparable among the records.

The amplitude of variability in the proxy measurements during the past $1.3 \mathrm{ka}$ is lower than earlier in the Holocene, due to the greater size and stability of the Kulusuk glaciers; however, it is worthwhile to examine the changes in the sediment properties where advances are interpreted as sustained above average PC1 values. The very high sediment accumulation rates during this interval $\left(0.8 \mathrm{~mm} \mathrm{yr}^{-1}\right)$ allow subannual XRF measurements and, if interpreted in the same manner as periods with smaller glacier size, can afford a detailed examination of changes in glacier size using the XRF PC1 data (Fig. 5). The overall trend reveals a small and very gradual glacier expansion after 0.7 ka followed by 20 th century retreat, which resembles the overall trend in Arctic temperatures over the last $2 \mathrm{ka}$ (Kaufman et al., 2009).
Multi-decadal variations in inferred glacier size during the past $1.3 \mathrm{ka}$ also appear to be synchronous with those of other glaciers in the region after ca. AD 1250 (Fig. 5). Kulusuk glaciers increased in size ca. AD 1250-1300 and again ca. AD 1450, similar to when ice caps on Baffin Island (Miller et al., 2012) and Iceland (Larsen et al., 2011) were expanding (Fig. 4). After AD 1450 Kulusuk glaciers continued to expand, as did Langjökull on Iceland, while evidence from the Baffin ice caps indicates continuous ice cover (Miller et al., 2012).

Both Kulusuk and Langjökull glaciers appear to have advanced in at least two phases, at ca. AD 1450-1630 and ca. AD 1700-1930. Magnetic susceptibility trends, linked to glacier size changes, from another high-resolution proglacial lake record on Baffin Island (Big Round Lake) reveal two 


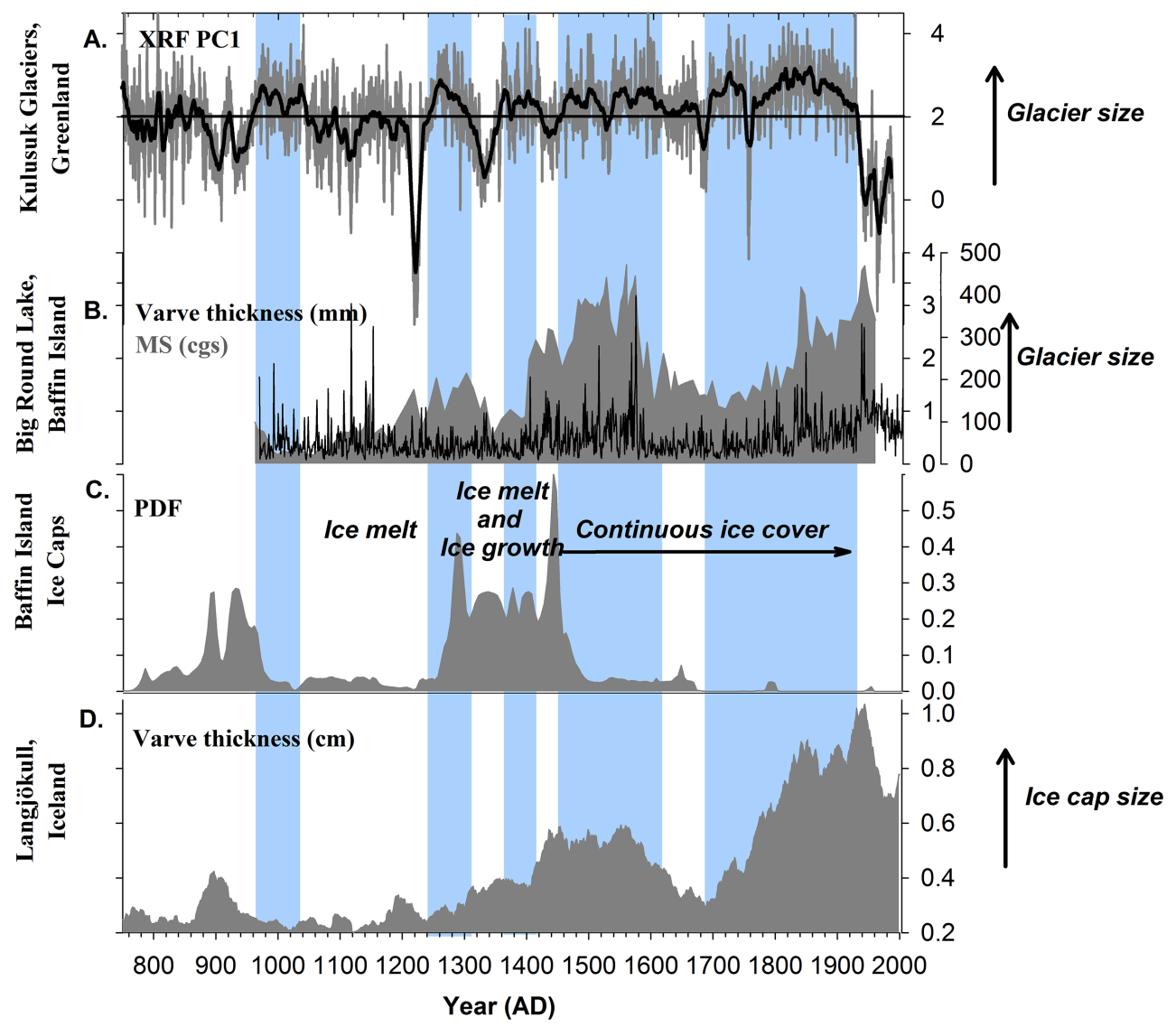

Figure 5. Change in the size of the Kulusuk glaciers since AD 700 compared with other high-resolution glacier and ice caps records from the region. (a) The Kulusuk PC1 record. Black horizontal line shows average value over this period. (b) Big Round Lake, Baffin Island, varve thickness and magnetic susceptibility (Thomas and Briner, 2009; Thomas et al., 2010). (c) Baffin Island ice cap activity reconstructed using vegetation kill dates with text showing original interpretations (Miller et al., 2012). (d) Langjökull ice cap, Iceland-based on varve thickness from Lake Hvítárvatn (Larsen et al., 2011). Blue shading marks periods of increased glacier size (sustained above average PC1 values).

similar distinct glacier advances at these times (Fig. 5) as well as an earlier advance ca. AD 1250-1300, which is also observed in the Kulusuk record (Thomas et al., 2010). However, varve thickness data from Big Round Lake, which has previously been interpreted to represent summer temperature, resemble trends in magnetic susceptibility (Thomas and Briner, 2009). This discrepancy can possibly be attributed to how the two proxies track different sedimentary processes operating over different timescales (annual vs. centennial), but without further analysis of those records we cannot account for this apparent contradiction. We argue that the magnetic susceptibility data from Big Round Lake are consistent with other data from around Greenland, indicating that the most extensive glacier advances since the early Holocene occurred between AD 1250 and 1900, and provide evidence for regionally coherent cooling phases during the Little Ice Age (Grove, 2001). We note that this timing contrasts with evidence from east Greenland that suggests the Istorvet Ice Cap advanced approximately 100 years earlier (ca. AD 1150;
Lowell et al., 2013), unless the data are reinterpreted as suggested by Miller et al. (2013).

Therefore, there seems to have been regional coherence in glacier activity not only during the past $1.3 \mathrm{ka}$, as previously suggested (Miller et al., 2012), but also during the past $4.1 \mathrm{ka}$, and glacier growth in response to episodic climate change has been a common feature in the North Atlantic region throughout, at least, the last $4.1 \mathrm{ka}$.

Cold events are an important feature of centennial-scale climate of the Holocene (Wanner et al., 2011). Cooling events in the North Atlantic region are possibly associated with changes in Atlantic Meridional Overturning Circulation (AMOC) (Denton and Broecker, 2008). IRD records suggest that periodic circulation changes of the North Atlantic Ocean resulted in an advection of cold, fresh surface water south and east during ice-rafting events throughout the Holocene (Bond et al., 1997). Ocean circulation and sea-surface temperature changes associated with IRD events have been attributed to solar forcing (Bond et al., 2001; Moffa-Sánchez et al., 2014; Jiang et al., 2015), and some modeling studies have 


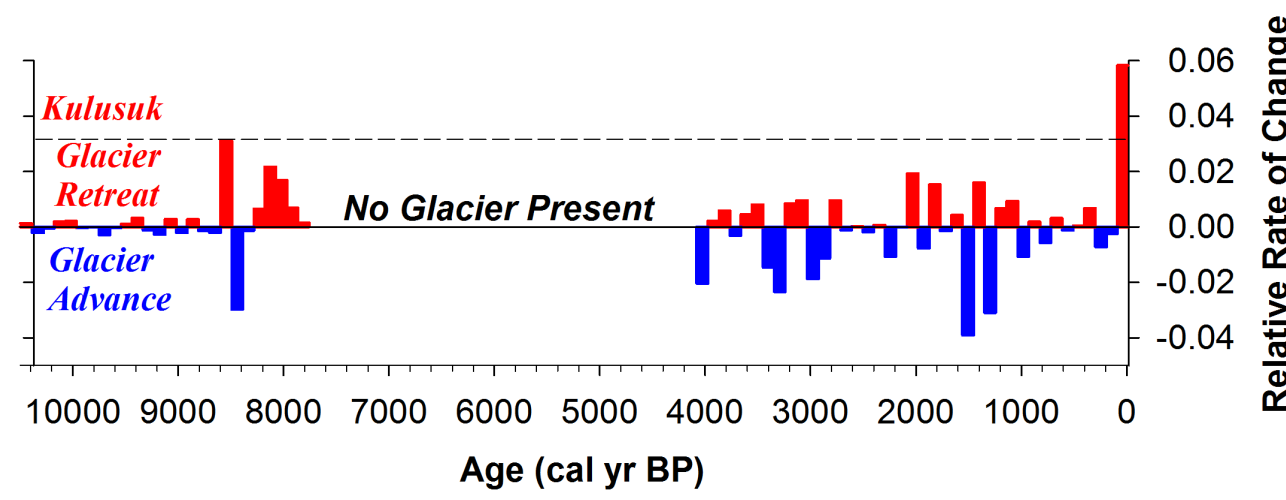

Figure 6. Relative rates of change in the size of the Kulusuk glaciers interpreted from scanning XRF PC1 data. Red bars show 105-year intervals when the average rate was positive indicating glacier retreat, and blue bars show intervals when the average rate was negative indicating glacier advance. Values not calculated during the mid-Holocene when we interpret glaciers to be absent.

confirmed that AMOC can switch between distinct modes in response to a small external forcing, such as solar variability (Jongma et al., 2007). However, modeling results are inconsistent and it is also possible that cooling events might have simply resulted from internal ocean dynamics (Schulz and Paul, 2002). Regardless of the mechanism, our results demonstrate that glaciers responded quite actively to natural climate variations of the Holocene.

\subsection{Rates of glacier change during the Holocene}

This well-dated, high-resolution record of changes in the size of the Kulusuk glaciers also allows comparison among the rates of past glacier size variations. We present relative rates of change inferred from the first derivative of the XRF PC1 data in 105-year binned averages, an interval chosen using the interval with the lowest resolution (Fig. 6). We acknowledge the caveat that they are based on the assumption that the relationship between minerogenic input and glacier size has remained constant. The analysis indicates that the rate of 20th century retreat of the Kulusuk glaciers was greater than during any other century of the past $1.3 \mathrm{ka}$, including during the Medieval Climate Anomaly. Furthermore, the 20th century retreat rate was $2-3$ times the rate of any other period of retreat during the past $4.1 \mathrm{ka}$, and almost twice as rapid as the early Holocene retreat that marked the transition into the regional HTM (Fig. 6). This comparison helps to place the rate of 20th century glacier loss in the context of natural episodes of past glacier activity.

\section{Conclusions}

The Kulusuk Lake sediment record was used to generate a high-resolution record of changes in the size of the Kulusuk glaciers over the last $9.5 \mathrm{ka}$. Characteristics of the lake and catchment limit the potential for sedimentation from nonglacial processes making it ideally situated to clearly capture changes related to glacier activity. The record shows that the glaciers were sensitive to a number of previously documented regional climate fluctuations and improves our understanding of Holocene climate dynamics in this sector of the Arctic. In particular, the record clearly constrains the Holocene Thermal Maximum at this site to between 7.8 and $4.1 \mathrm{ka}$, when the glaciers likely completely melted away. The regrowth of the Kulusuk glaciers at 4.1 ka corresponds with regional hydrologic changes and reflects the onset of the Neoglacial period. The last $4.1 \mathrm{ka}$ is marked by a series of abrupt glacier advances as the size of the Kulusuk glaciers increased. These episodes of glacier growth correspond with ice rafting events in the North Atlantic Ocean, as well as regional ice cap expansion, and demonstrate that glaciers in this sector of the Arctic were very active during the late Holocene in response to abrupt cooling events that punctuated millennial-scale insolation-driven cooling. The reconstruction of Kulusuk glacier activity provides a new and refined perspective on late Holocene cold events, which are important features of centennial-scale climate variability.

Acknowledgements. This research was supported by a LDEO Postdoctoral Fellowship to NLB, NSF grant ARC-0851642 to WJD, NOAA grant NA09OAR4600215 and NSF grant ARC0909354 to RSB. We thank Lucien von Gunten, Sam Davin, and Greg de Wet for assistance with field work, as well as Jason Briner, Anders Carlson, and three anonymous reviewers for comments on earlier drafts.

Edited by: V. Rath

\section{References}

Balascio, N. L., D’Andrea, W. J., Bradley, R. S., and Perren, B. B.: Biogeochemial evidence for hydrologic changes during the Holocene in a lake sediment record from southeast Greenland, The Holocene, 23, 1428-1439, 2013.

Bennike, O. and Sparrenbom, C. J.: Dating of the Narssarssuaq stade in southern Greenland, The Holocene, 17, 279-282, 2007. 
Berger, A. and Loutre, M. F.: Insolation values for the climate of the last 10 million years, Quat. Sci. Rev., 10, 297-317, 1991.

Bond, G., Showers, W., Cheseby, M., Lotti, R., Almasi, P., deMenocal, P., Priore, P., Cullen, H., Hajdas, I., and Bonani, G.: A pervasive millennial-scale cycle in North Atlantic Holocene and Glacial climates, Science, 278, 1257-1266, 1997.

Bond, G., Kromer, B., Beer, J., Muscheler, R., Evans, M. N., Showers, W., Hoffmann, S., Lotti-Bond, R., Hajdas, I., and Bonani, G.: Persistent solar influence on North Atlantic climate during the Holocene, Science, 294, 2130-2136, 2001.

Bridgwater, D.: Nagssustoqidian mobile belt in East Greenland, Geology of Greenland, 7, 97-103, 1976.

Croudace, I. W., Rindby, A., and Rothwell, R. G.: ITRAX: description and evaluation of a new multi-function X-ray core scanner, in: New Techniques in Sediment Core Analysis, edited by: Rothwell, R. G., Geological Society, London, Special Publications 267, 51-564, 2006.

Dahl, S. O., Bakke, J., Lie, Ø., and Nesje, A.: Reconstruction of former glacier equilibrium-line altitudes based on proglacial sites: an evaluation of approaches and selection of sites, Quat. Sci. Rev., 22, 275-287, 2003.

D'Andrea, W. J., Huang, Y., Fritz, S. C., and Anderson, N. J.: Abrupt Holocene climate change as an important factor for human migration in West Greenland, Proc. Natl. Acad. Sci., 108, 9765-9769, 2011.

Dean, W. E.: Determination of carbonate and organic matter in calcareous sediments and sedimentary rocks by loss on ignition: comparison with other methods, J. Sed. Petrol., 44, 242-248, 1974.

Denton, G. H. and Broecker, W. S.: Wobbly ocean conveyor circulation during the Holocene, Quat. Sci. Rev., 27, 1939-1950, 2008.

Dyurgerov, M. and Meier, M. F.: Glaciers and the Changing Earth System: A 2004 Snapshot, Occasional Paper 58, Institute of Arctic and Alpine Research, University of Colorado, Boulder, CO, 118 pp., 2005.

Ellison, C. R. W., Chapman, M. R., and Hall, I. R.: Surface and deep ocean interactions during the cold climate event 8200 years ago, Science, 312, 1929-1932, 2006.

Giraudeau, J., Cremer, M., Manthé, S., Labeyrie, L., and Bond, G.: Coccolith evidence for instabilities in surface circulation south of Iceland during Holocene times, Earth and Planet. Sci. Lett., 179, 257-268, 2000

Grove, J. M.: The initiation of the "Little Ice Age" in regions round the North Atlantic, Climatic Change, 48, 53-82, 2001.

Humlum, O. and Christiansen, H. H.: Geomorphology of the Ammassalik Island, SE Greenland, Geografisk Tidsskrift-Danish J. Geog., 108, 5-20, 2008.

Huybrechts, P.: Late Weichselian relative sea-level changes and ice sheet history in southeast Greenland, Earth Planet. Sci. Lett., 272, 8-18, 2008.

Jansson, P., Rosqvist, G., and Schneider, T.: Glacier fluctuations, suspended sediment flux and glacio-lacustrine sedimensts, Geografiska Annaler Series A, Phys. Geogr., 87, 37-50, 2005.

Jennings, A. E., Knudsen, K. L., Hald, M., Hansen, C. V., and Andrews, J. T.: A mid-Holocene shift in Arctic sea-ice variability on the East Greenland Shelf, The Holocene, 12, 49-58, 2002.

Jiang, H., Muscheler, R., Björck, S., Seidenkrantz, M.-S., Olsen, J., Sha, L., Sjolte, J., Eiriksson, J., Ran, L., Knudsen, K.-L., and
Knudsen, M. F.: Solar forcing of Holocene summer sea-surface temperatures in the northern North Atlantic, Geology, 43, 203 206, 2015.

Jongma, J. I., Prange, M., Renssen, H., and Schulz, M.: Amplification of Holocene multicentennial climate forcing by mode transitions in North Atlantic overturning circulation, Geophys. Res. Lett., 34, L15706, doi:10.1029/2007GL030642, 2007.

Kaufman, D. S., Ager, T. A., Anderson, N. J., Anderson, P. M., Andrews, J. T., Bartlein, P. J., Brubaker, L. B., Coats, L. L., Cwynar, L. C., Duvall, M. L., Dyke, A. S., Edwards, M. E., Eisner, W. R., Gajewski, K., Geirsdóttir, A., Hu, F. S., Jennings, A. E., Kaplan, M. R., Kerwin, M. W., Lozhkin, A. V., MacDonald, G. M., Miller, G. H., Mock, C. J., Oswald, W. W., Otto-Bliesner, B. L., Porinchu, D. F., Rühland, K., Smol, J. P., Steig, E. J., and Wolfe, B. B.: Holocene thermal maximum in the western Arctic (0-180 W), Quat. Sci. Rev., 23, 529-560, 2004.

Kaufman, D. S., Schneider, D. P., McKay, N. P., Ammann, C. M., Bradley, R. S., Briffa, K. R., Miller, G. H., Otto-Bliesner, B. L., Overpeck, J. T., and Vinther, B. M.: Arctic Lakes 2k Project Members: Recent warming reverses long-term Arctic cooling, Science, 325, 1236-1239, 2009.

Kelly, M. A. and Lowell, T. V.: Fluctuations of local glaciers in Greenland during latest Pleistocene and Holocene time, Quat. Sci. Rev., 28, 2088-2106, 2009.

Kissel, C., Van Toer, A., Laj, C., Cortijo, E., and Michel, E.: Variations in the strength of the North Atlantic bottom water during Holocene, Earth and Planet. Sci. Lett., 369/370, 248-259, 2013.

Kobashi, T., Kawamura, K., Severinghaus, J. P., Barnola, J.-M., Nakaegawa, T., Vinther, B. M., Johnsen, S. J., and Box, J. E.: High variability of Greenland surface temperature over the past 4000 years estimated from trapped air in an ice core. Geophys. Res. Lett., 38, L21501, doi:10.1029/2011GL049444, 2011.

Larsen, D. J., Miller, G. H., Geirsdóttir, Á., and Thordarson, T.: A 3000-year varved record of glacier activity and climate change from the proglacial lake Hvítárvatn, Iceland, Quat. Sci. Rev., 30, 2715-2731, 2011.

Larsen, D. J. Miller, G. H., Geirsdóttir, Á., and Ólafsdóttir, S.: Nonlinear Holocene climate evolution in the North Atlantic: a highresolution, multi-proxy record of glacier activity and environmental change from Hvítárvatn, central Iceland, Quat. Sci. Rev., 39, 14-25, 2012.

Larsen, N. K., Kjær, K. H., Lecavalier, B., Bjørk, A. A., Colding, S., Huybrechts, P., Jakobsen, K. E., Kjeldsen, K. K., Knudsen, K.L., Odgaard, B. V., and Olsen, J.: The response of the southern Greenland ice sheet to the Holocene thermal maximum, Geology, 43, 291-294, 2015.

Levy, L. B., Kelly, M. A., Lowell, T. V., Hall, B. L., Hempel, L. A., Honsaker, W. M., Lusas, A. R., Howley, J. A., and Axford, Y. L.: Holocene fluctuations of Bregne ice cap, Scoresby Sund, east Greenland: a proxy for clmate along the Greenland Ice Sheet margin, Quat. Sci. Rev., 92, 357-368, 2014.

Long, A. J., Roberts, D. H., Simpson, M. J. R., Dawson, S., Milne, G. A., and

Lowell, T. V., Hall, B. L., Kelly, M. A., Bennike, O., Lusas, A. R., Honsaker, W., Smith, C. A., Levy, L. B., Travis, S., and Denton, G. H.: Late Holocene expansion of Istorvet ice cap, Liverpool Land east Greenland, Quat. Sci. Rev., 63, 128-140, 2013.

Meier, M. F.: Glaciers dominate eustatic sea-level rise in the $21 \mathrm{st}$ century, Science, 317, 1064-1067, 2007. 
Miller, G. H., Brigham-Grette, J., Alley, R. B., Anderson, L., Bauch, H. A., Douglas, M. S. V., Edwards, M. E., Elias, S. A., Finney, B. P., Fitzpatrick, J. J., Funder, S. V., Herbert, T. D., Hinzman, L. D., Kaufman, D. S., MacDonald, G. M., Polyak, L., Robock, A., Serreze, M. C., Smol, J. P., Speilhagen, R., White, J. W. C., Wolfe, A. P., and Wolff, E. W.: Temperature and precipitation history of the Arctic, Quat. Sci. Rev., 29, 1679-1715, 2010.

Miller, G. H., Geirsdóttir, Á., Zhong, Y., Larsen, D. J., OttoBliesner, B. L., Holland, M. M., Bailey, D. A., Refsnider, K. A., Lehman, S. J., Southon, J. R., Anderson, C., Björnsson, H., and Thordarson, T.: Abrupt onset of the Little Ice Age triggered by volcanism and sustained by sea-ice/ocean feedbacks, Geophys. Res. Lett., 39, L02708, doi:10.1029/2011GL050168, 2012.

Miller, G. H., Briner, J. P., Refsnider, K. A., Lehman, S. J., Geirsdóttir, Á., Larsen, D. J., and Southon, J. R.: Substantial agreement on the timing and magnitude of Late Holocene ice cap expansion between East Greenland and the Eastern Canadian Arctic: a commentary on Lowell et al., 2013, Quat. Sci. Rev., 77, 239-245, 2013.

Moffa-Sánchez, P., Born, A., Hall, I. R., Thornalley, D. J. R., and Barker, S.: Solar forcing of North Atlantic surface temperature and salinity over the past millennium, Nat. Geosci., 7, 275-278, 2014.

Nesje, A., Dahl, S. O., Andersson, C., and Matthews, J. A.: The lacustrine sedimentary sequence in Sygneskardvatnet, western Norway: a continuous, high-resolution record of the Jostedalsbreen ice cap during the Holocene, Quat. Sci. Rev., 19, 10471065, 2000.

Oerlemans, J.: Extracting a climate signal from 169 glacier records, Science, 308, 675-677, 2005.

Olsen, J., Anderson, N. J., and Knudsen, M. F.: Variability of the North Atlantic Oscillation over the past 5,200 years, Nat. Geosci., 5, 808-812, 2012.

Ran, L., Jiang, H., Knudsen, K. L., and Eiríksson, J.: A highresolution Holocene diatom record on the North Icelandic shelf, Boreas, 37, 399-413, 2008.

Reimer, P. J., Baillie, M. G. L., Bard, E., Bayliss, A., Beck, J. W., Blackwell, P. G., Bronk Ramsey, C., Buck, C. E., Burr, G. S., Edwards, R. L., Friedrich, M., Grootes, P. M., Guilderson, T. P., Hajdas, I., Heaton, T. J., Hogg, A. G., Hughen, K. A., Kaiser, K. F., Kromer, B., McCormac, F. G., Manning, S. W., Reimer, R. W., Richards, D. A., Southon, J. R., Talamo, S., Turney, C. S. M., van der Plicht, J., and Weyhenmeyer, C. E.: IntCal09 and Marine09 radiocarbon age calibration curves, 0-50 000 years cal BP, Radiocarbon, 51, 1111-1150, 2009.

Roberts, D. H., Long, A. J., Schnabel, C., Freeman, S., and Simpson, M. J. R.: The deglacial history of southeast sector of the Greenland Ice Sheet during the Last Glacial Maximum, Quat. Sci. Rev., 27, 1505-1516, 2008.
Rothwell, R. G., Hoogakker, B., Thomson, J., Croudace, I. W., and Frenz, M.: Turbidite emplacement on the southern Balearic Abyssal Plain (western Mediterranean Sea) during Marine Isotope Stages 1-3: An application of ITRAX XRF scanning of sediment cores to lithostratigraphic analysis, in: New techniques in sediment core analysis, edited by: Rothwell, R. G., Special Publications, Geological Society, London, 79-98, 2006.

Schulz, M. and Paul, A.: Holocene climate variability on centennialto-millennial time scales: 1. Climate records from the NorthAtlantic realm, in: Climate Development and History of the North Atlantic Realm, edited by: Wefer, G., Berger, W.H., Behre, K.-E., and Jansen, E., Berlin, Springer, 41-54, 2002.

Stuiver, M. and Reimer, P. J.: Extended ${ }^{14} \mathrm{C}$ database and revised CALIB radiocarbon calibration program, Radiocarbon, 35, 215230, 1993.

Thomas, E. K. and Briner, J. P.: Climate of the past millennium inferred from varved proglacial lake sediments on northeast Baffin Island, Arctic Canada, J. Paleolim., 41, 209-224, 2009.

Thomas, E. K., Szymanski, J., and Briner, J. P.: Holocene alpine glaciation inferred from lacustrine sediments on northeastern Baffin Island, Arctic Canada, J. Quat. Sci., 25, 146-161, 2010.

Thomas, E. R., Wolff, E. W., Mulvaney, R., Steffensen, J., Johnsen, S. J., Arrowsmith, C., White, J. W. C., Vaughn, B., and Popp, T.: The $8.2 \mathrm{ka}$ event from Greenland ice cores, Quat. Sci. Rev., 26, 70-81, 2007.

Thornalley, D. J. R., Elderfield, H., and McCave, I. N.: Holocene oscillations in temperature and salinity of the surface subpolar North Atlantic, Nature, 457, 711-714, 2009.

Young, N. E., Briner, J. P., Axford, Y., Csatho, B., Babonis, G. S., Rood, D. H., and Finkel, R. C.: Response of a marine-terminating Greenland outlet glacier to abrupt cooling 8200 and 9300 years ago, Geophys. Res. Lett., 38, L24701, doi:10.1029/2011GL049639, 2011.

Young, N. E., Briner, J. P., Rood, D. H., Finkel, R. C., Corbett, L. B., and Bierman, P. R.: Age of the Fjord Stade moraines in the Disko Bugt region, western Greenland, and the 9.3 and 8.2 ka cooling events, Quat. Sci. Rev., 60, 76-90, 2013.

Wanner, H., Solomina, O., Grosjean, M., Ritz, S. P., and Jetel, M.: Structure and origin of Holocene cold events, Quat. Sci. Rev., 30, 3109-3123, 2011.

Winsor, K., Carlson, A. E., and Rood, D. H.: ${ }^{10}$ Be dating of the Narsarsuaq moraine in southernmost Greenland: evidence for a late-Holocene ice advance exceeding the Little Ice Age maximum, Quat. Sci. Rev., 98, 135-143, 2004.

Zemp, M., Frey, H., Gärtner-Roer, I., Nussbaumer, S. U., Hoelzle, M., Paul, F., and Haeberli, W.: Fluctuations of glaciers 2005-2010, Vol. X: World Glacier Monitoring Service, Zurich, Switzerland, 336 pp., 2010. 